\title{
Chromosome aberrations in workers of beach sand mineral industries
}

\author{
C. MEENAKSHI, Mary N. MOHANKUMAR*
}

(Manuscript received 20 January 2013, accepted 15 May 2013)

\begin{abstract}
Beach Sand Mining (BSM) is a profitable industry earning a sizable income for the country by way of foreign exchange. The Indian coast is rich in rare earths such as ilmenite, rutile, leucoxene, zircon, garnet and sillimanite, and is invariably associated with radioactive monazite. Due to the nature of the separation processes involved and the manual handling, workers in these factories are continuously being exposed to suspended particles containing naturally occurring radioactive materials. An attempt was made to estimate DNA damage using a chromosome aberration assay to monitor radiation effects in workers of BSM industries in India. The study group comprised 27 BSM workers and 20 controls. Percentage yields of dicentrics, acentric fragments and chromatid breaks observed in the control group were $0.058 \pm 0.017$, $0.073 \pm 0.03$ and $0.22 \pm 0.112$, respectively. Percentage yields of dicentrics + centric rings, acentric fragments and chromatid breaks observed in the BSM group were $0.029 \pm 0.01$ ( $P$ value 0.19$), 0.24 \pm 0.06$ ( $P$ value 0.006$)$ and $0.455 \pm 0.06$ ( $P$ value 0.0004), respectively. Elevated levels of fragments and chromatid aberrations are suggestive of low-dose radiation effects and also chemically-induced DNA damage.
\end{abstract}

Keywords: chromosome aberration / beach sand mining / radiation worker / radon

\section{Introduction}

Beach Sand Mining (BSM) of minerals such as ilmenite, rutile, leucoxene, zircon, garnet and sillimanite, etc., is a profitable industry in countries such as Australia, Vietnam and India. The highest concentration of Total Heavy Minerals (THM) in Indian beach sand is found in the Chavara deposit (70-80\% $\mathrm{THM}$ with $60 \% \mathrm{TiO}_{2}$ ) and Manavalakurichi areas (60-80\% THM with 50\% $\left.\mathrm{TiO}_{2}\right)(\mathrm{Babu}$ et al., 2009). Nevertheless, the beach sand on the Indian coast is invariably associated with radioactive thorium-bearing monazite. The measured natural radionuclide content of thorium in soil in India ranges from 14-160 Bq/Kg (UNSCEAR, 2008). Among these heavy minerals, ilmenite is the largest constituent, followed by sillimanite and garnet. While thorium and rare earth elements from these beach sands are solely processed by Indian Rare Earths Ltd., a Government of India enterprise, garnet, ilmenite and sillimanite mining are licensed to private agencies. However, the separation process, though mechanical in nature, is mostly carried out by backyard processing methods in improvised sheds that lead to the generation of

Radiological Safety Division, Indira Gandhi Centre for Atomic Research (IGCAR), Kalpakkam-603102, Tamilnadu, India. * e-mail: marynmk@gmail.com 
particulate matter to which workers are exposed. These particles include NORM dust containing silica and heavy metal-bearing ilmenite, that may be inhaled and ingested.

The Atomic Energy Regulatory Board of India recommends routine monitoring of radiation levels in BSM workplaces using physical dosimeters. Nevertheless, personnel employed in these industries are not considered radiation workers as the doses received by them are estimated to be far below those likely to be received in the nuclear industries. Using physical dosimetry and computational methods, these workers were estimated to receive doses ranging from 2.3-6 mSv/year (Suresh et al., 2003; Haridasan et al., 2006). Nevertheless, the health effects of gross exposure to radon, thoron progeny and suspended particles cannot be estimated by physical dosimetry.

The chromosome aberration assay is a proven method to measure DNA damage and also estimate doses in the absence of physical dosimeters, especially in cases involving real or suspected accidental exposures. In such situations, the study of early biological effects induced by exposure to ionizing radiation has been proposed as either a complementary or an alternative method for dose assessment (Ramalho and Nascimento, 1991; IAEA, 2001; Voisin et al., 2001). Although biological dosimetry is not applied to determine internal contamination, biological responses aid in comprehending the significance of the dose measured, and subsequently the risks involved.

As no data exists on cytogenetic damage among BSM workers in India, the present investigation was undertaken. Chromosome aberrations were scored in blood lymphocytes of workers engaged in the BSM industries and compared with a control group to examine aberrations due to radiation and other mutagens in the work environment.

\section{Materials and methods}

\subsection{Study group and sample collection}

The study was conducted during April 2010 and the group comprised 27 permanent BSM employees (25 men and 2 women) engaged in quality control and administration. These employees had been working for 6-15 years ( 8 hours per day; 6 days per week) and their workplace was close to the processing area. Among these were 6 smokers; 2 of the smokers were also tobacco chewers. Most of the smokers were also light alcoholics (Tab. I). In the control group there were 20 apparently healthy men (6 smokers and 14 non-smokers), not engaged in processing plants or 
TABLE I

Individual data and chromosome aberrations in BSM workers.

\begin{tabular}{|c|c|c|c|c|c|c|c|c|c|}
\hline Subjects & Age & Sex & $\begin{array}{c}\text { Working } \\
\text { yrs }\end{array}$ & $\begin{array}{c}\text { Personal } \\
\text { habits }\end{array}$ & $\begin{array}{c}\text { Cells } \\
\text { scored }\end{array}$ & dic & ace & chtb & $\mathbf{r}$ \\
\hline BSM-1 & 40 & $\mathrm{M}$ & 7 & NONE & 1118 & 0 & 0 & 3 & 0 \\
\hline BSM-2 & 38 & M & 10 & $S \& D$ & 849 & 0 & 0 & 8 & 0 \\
\hline BSM-3 & 35 & M & 9 & $S \& D$ & 1043 & 0 & 0 & 6 & 0 \\
\hline BSM-4 & 34 & M & 7 & NONE & 1387 & 0 & 1 & 7 & 0 \\
\hline BSM-5 & 32 & M & 12 & NONE & 1321 & 0 & 7 & 5 & 0 \\
\hline BSM-6 & 27 & M & 2 & S, D \& TC & 1019 & 0 & 0 & 1 & 0 \\
\hline BSM-7 & 35 & M & 7 & NONE & 504 & 0 & 1 & 1 & 0 \\
\hline BSM-8 & 36 & M & 12 & NONE & 1541 & 0 & 4 & 4 & 0 \\
\hline BSM-9 & 40 & M & 2 & NONE & 1469 & 0 & 4 & 6 & 0 \\
\hline BSM-10 & 30 & M & 5 & S, D \& TC & 421 & 0 & 1 & 0 & 0 \\
\hline BSM-11 & 31 & M & 9 & NONE & 806 & 0 & 0 & 3 & 0 \\
\hline BSM-12 & 37 & M & 14 & $S \& D$ & 873 & 0 & 1 & 5 & 0 \\
\hline BSM-13 & 28 & M & 8 & D & 424 & 0 & 0 & 1 & 0 \\
\hline BSM-14 & 45 & M & 20 & NONE & 1119 & 0 & 1 & 4 & 0 \\
\hline BSM-15 & 34 & M & 8 & NONE & 421 & 0 & 0 & 0 & 0 \\
\hline BSM-16 & 35 & M & 2 & NONE & 328 & 0 & 0 & 0 & 0 \\
\hline BSM-17 & 31 & M & 9 & NONE & 959 & 2 & 3 & 4 & 1 \\
\hline BSM-18 & 38 & M & 8 & NONE & 1319 & 0 & 2 & 10 & 0 \\
\hline BSM-19 & 29 & M & 9 & NONE & 1994 & 0 & 11 & 11 & 1 \\
\hline BSM-20 & 40 & $\mathrm{~F}$ & 6 & NONE & 1305 & 1 & 13 & 7 & 0 \\
\hline BSM-21 & 32 & M & 6 & NONE & 1253 & 1 & 2 & 6 & 0 \\
\hline BSM-22 & 34 & F & 11 & NONE & 1065 & 1 & 15 & 12 & 0 \\
\hline BSM-23 & 42 & M & 7 & NONE & 866 & 0 & 2 & 4 & 0 \\
\hline BSM-24 & 30 & M & 5 & NONE & 1029 & 0 & 2 & 3 & 0 \\
\hline BSM-25 & 43 & M & 18 & NONE & 1003 & 0 & 1 & 4 & 0 \\
\hline BSM-26 & 28 & M & 5 & NONE & 1020 & 0 & 3 & 6 & 0 \\
\hline BSM-27 & 37 & M & 15 & S \& D & 1205 & 1 & 6 & 17 & 1 \\
\hline
\end{tabular}

in radiation-related work. All smokers (in both groups) smoked less than 10 cigarettes per day for periods ranging between 12 and 20 years. None of the subjects in the control group were alcoholics (Tab. II). The control group and BSM workers belonged to the same ethnic group.

All the subjects were informed about the purpose and procedure of the study and they signed an informed consent form. They were also asked to fill out a detailed questionnaire to obtain information regarding age, personal habits, alcohol consumption, and frequency and period of smoking (details provided in Tab. I). 
TABLE II

Chromosome aberrations in blood lymphocytes of controls.

\begin{tabular}{cccccccccc}
\hline $\begin{array}{c}\text { Subjects } \\
\text { (Non-smokers) }\end{array}$ & Age & Sex & $\begin{array}{c}\text { Working } \\
\text { years }\end{array}$ & $\begin{array}{c}\text { Personal } \\
\text { habits }\end{array}$ & $\begin{array}{c}\text { Cells } \\
\text { scored }\end{array}$ & dic & ace & chtb & r \\
\hline 1 & 32 & M & 9 & NONE & 990 & 0 & 0 & 0 & 0 \\
2 & 34 & M & 10 & NONE & 998 & 0 & 0 & 0 & 0 \\
3 & 37 & M & 12 & NONE & 508 & 0 & 0 & 0 & 0 \\
4 & 24 & M & 1 & NONE & 738 & 0 & 2 & 0 & 0 \\
5 & 30 & M & 6 & NONE & 438 & 0 & 0 & 0 & 0 \\
6 & 29 & M & 3 & NONE & 512 & 0 & 0 & 0 & 0 \\
7 & 54 & M & 17 & NONE & 486 & 0 & 0 & 0 & 0 \\
8 & 42 & M & 16 & NONE & 506 & 0 & 0 & 0 & 0 \\
9 & 36 & M & 8 & NONE & 698 & 0 & 0 & 0 & 0 \\
10 & 44 & M & 10 & NONE & 580 & 0 & 0 & 0 & 0 \\
11 & 38 & M & 9 & NONE & 500 & 1 & 0 & 0 & 0 \\
12 & 40 & M & 14 & NONE & 1150 & 1 & 0 & 2 & 0 \\
13 & 28 & M & 5 & NONE & 540 & 1 & 0 & 0 & 0 \\
14 & 33 & M & 10 & NONE & 560 & 1 & 0 & 2 & 0 \\
15 & 37 & M & 11 & S & 1157 & 0 & 0 & 2 & 0 \\
16 & 44 & M & 16 & S & 678 & 0 & 0 & 0 & 0 \\
17 & 29 & M & 6 & S & 1100 & 1 & 7 & 2 & 0 \\
18 & 34 & M & 8 & S & 989 & 1 & 2 & 4 & 0 \\
\hline 19 & 35 & M & 9 & S & 540 & 1 & 2 & 1 & 0 \\
\hline & 40 & M & 6 & S & 580 & 1 & 0 & 8 & 0 \\
\hline
\end{tabular}

(S-smoker, dic-dicentric, ace-acentric fragments, chtb-chromatid break, r-centric ring).

\subsection{Chromosome aberration assay}

Blood samples were collected using heparinized vacuette tubes (Greiner Labortechnik, Austria) by venipuncture. About $1 \mathrm{ml}$ of whole blood was added to $9 \mathrm{ml}$ of RPMI 1640 containing $100 \mathrm{U} / \mathrm{ml}$ penicillin, $100 \mu \mathrm{g} / \mathrm{ml}$ streptomycin and $1 \mathrm{ml}$ of fetal bovine serum (Himedia). Bromodeoxyuridine to a final concentration of $10 \mu \mathrm{M}$ was added to the culture to differentiate first-division cells. Cultures were initiated by the addition of $5 \mu \mathrm{g} / \mathrm{ml}$ phytohemagglutinin (Gibco) and incubated for 48 hours in a $5 \% \mathrm{CO}_{2}$ atmosphere. At the 45 th hour, colchicine (Sigma) to a final concentration of $0.04 \mu \mathrm{g} / \mathrm{ml}$, was added to arrest cells at metaphase. Cultures were harvested at 48 hours and subjected to a hypotonic treatment of $0.56 \% \mathrm{KCl}$. Cells were washed and suspended in Carnoy's fixative and cast on microscope slides. The slides were stained with Hoechst for 10 minutes, washed with McIlvaine's buffer, mounted temporarily with a cover-slip, exposed to sunlight for 2 hours in humid conditions, washed with McIlvaine's buffer and stained with Giemsa. 
Metaphases were captured using an automated metaphase finder system (Metasystems, Germany). Individual, complete metaphases were carefully analyzed for aberrations and noted onto scoring sheets. The following aberrations were scored: dicentric (dic, a chromosome with two centromeres along with its associated fragment), acentric fragments (ace, a pair of broken portions of chromatid arms which may or may not be lying in the close vicinity of the original chromosomes), breaks (chtb, damage to a chromatid involving a discontinuity of the chromosomes greater than the width of the chromatid) and centric ring ( $r$, a ringshaped chromosome resulting from an exchange between two breaks occurring on either side of the centromere).

\subsection{Statistical methods}

Statistical analyses were performed using the INSTAT software. The Tukey multiple comparison ANOVA test was used to compare aberrations between the groups. Statistically significant differences were tested at $1 \%$ and $5 \%$ levels. Correlation was calculated according to Spearman and the level of significance set at 95\% $(\alpha=0.05)$.

\section{Results and discussion}

The measurement of dicentric chromosomes in human peripheral blood lymphocytes is the internationally recommended golden standard for radiation biodosimetry as it is highly radiation-specific (IAEA, 2001).

The mean percentages of dic $+\mathrm{r}$, ace and chtb observed from 27 BSM workers in 27661 cells were $0.029 \pm 0.013,0.24 \pm 0.06$ and $0.455 \pm 0.061$, respectively. The mean percentages of spontaneous dic, ace and chtb observed from 20 control donors in 14248 cells were $0.058 \pm 0.017,0.073 \pm 0.03$ and $0.22 \pm 0.112$, respectively. The mean percentages of dic $+r$, ace and chtd among the nonsmoking BSM worker group were $0.028 \pm 0.015,0.279 \pm 0.075$ and $0.414 \pm 0.052$, respectively. The mean percentages of dic $+\mathrm{r}$, ace and chtd in the age-matched non-smoking control group were $0.045 \pm 0.020,0.019 \pm 0.019$ and $0.037 \pm 0.026$, respectively (Tab. III).

Reports on chromosome aberrations in workers employed in the mining industries have yielded valuable information to draw the attention of regulatory bodies worldwide (Padmala Reddy et al., 2000; Lloyd et al., 2001; Smerhovsky et al., 2002). Underground miners are particularly exposed to complex mixtures of chemicals such as heavy metals, diesel emission particles and dust, many of which are known mutagens (Johnson, 1998; Keshava and Ong, 1999; Rojas et al., 1999; Scheepers et al., 2002; Donbak et al., 2005). 
TABLE III

Chromosome aberrations in blood lymphocytes of controls and BSM workers.

\begin{tabular}{ccccccc}
\hline $\begin{array}{c}\text { Sl. } \\
\text { No. }\end{array}$ & Group of workers & $\begin{array}{c}\text { No. of } \\
\text { donors }\end{array}$ & $\begin{array}{c}\text { No. of } \\
\text { cells }\end{array}$ & $\begin{array}{c}\text { Dicentric }+ \\
\text { rings } \\
(\% \pm \text { S.E.M })\end{array}$ & $\begin{array}{c}\text { Acentric } \\
\text { fragments } \\
(\% \pm \text { S.E.M) }\end{array}$ & $\begin{array}{c}\text { Chromatid } \\
\text { breaks } \\
(\% \pm \text { S.E.M) }\end{array}$ \\
\hline 1 & Controls (6S+14NS) & 20 & 14248 & $0.058 \pm 0.017$ & $0.0735 \pm 0.03$ & $0.22 \pm 0.112$ \\
\hline 2 & BSM (6S+21NS) & 27 & 27661 & $0.029 \pm 0.013$ & $0.24 \pm 0.06$ & $0.455 \pm 0.061$ \\
\hline 3 & Controls (NS) & 14 & 9204 & $0.045 \pm 0.020$ & $0.019 \pm 0.019$ & $0.037 \pm 0.026$ \\
4 & BSM (NS) & 21 & 22251 & $0.028 \pm 0.015$ & $0.279 \pm 0.075$ & $0.414 \pm 0.052$ \\
\hline & P value (Tukey test) & & 0.38 & $0.0088^{*}$ & $0.0012 *$ \\
\hline
\end{tabular}

* Very significant.

Nevertheless, reports show varied results. Many indicate increased frequencies of chromosomal aberrations (Deknudt et al., 1973; Bauchinger et al., 1976; Lazutka et al., 1999; Keshava and Ong, 1999; Topaktas et al., 2002; Wolf et al., 2004). However, Nordenson et al. (1982) failed to observe any significant increase in the frequency of chromosomal aberrations in lead miners. Maki-Paakanen et al. (1981) reported higher frequencies of chromosomal aberrations and sister chromatid exchanges (SCEs) only in smokers of workers exposed to lead in a smeltery. These reports largely attribute the elevated frequencies to occupational exposure to complex mixtures of genotoxic compounds such as heavy metals, diesel emission particles, organic solvents and mine dust.

Cytogenetic studies on occupational workers including miners exposed to Naturally Occurring Radioactive Materials (NORM) and those employed in nuclear fuel manufacturing also indicate elevated levels of chromosomal aberrations such as gaps, breaks, acentric fragments, exchanges, dicentrics and polyploids (Martin et al., 1991; Al-sabti et al., 1992; Kandar and Bahari, 1995; Prabhavathi et al., 2000; Dias et al., 2007). Leonard et al. (1984) analyzed chromosome aberrations in 59 workers of coal-fueled power plants and 89 workers of nuclear power plants and reported a significant elevation in acentric fragments and dicentric chromosomes in both types of workers compared with the control group. These reports largely attribute the elevated frequencies to occupational exposure to low doses of ionizing radiation and smoking.

Reports show a significant association between smoking and stable aberrations (translocations and insertions) measured by the FISH technique, and also agerelated increases in dicentrics and acentric fragments (Ramsey et al., 1995; Tucker, 2008). Pressl et al. (1999) observed an insignificant increase in FISH-detected translocations with smoking and also observed a strong association with age. Smoking is also known to induce chromatid breaks and fragments (Sinues et al., 1990; Bilban and Jakopin, 2005; Meenakshi and Mohankumar, 2012). Hence, the 
data obtained in the present study was also analyzed after deleting the smokers (smokers, tobacco-chewers and alcoholics) from both the controls and the BSM group. Table III presents the analysis of this data. The Tukey multiple comparison test of aberrations (dic $+r$, ace and chtd) within the four groups (BSM smokers, BSM non-smokers, BSM controls and controls) showed significant increases in the percentages of ace and chtd but not in dic $+r$.

While fragments could have been produced by radiation-induced doublestrand breaks, chromatid aberrations are known to be biomarkers of exposure to chemicals (Anwar, 1997) and not normally considered to reflect exposure to radiation. However, a recent report indicates radiation induces chromatid aberrations (Tanaka et al., 2008; Tanaka and Kamada, 2009).

Interestingly, the extremely significant increase in the percentage of chromatid aberrations $(0.414 \pm 0.05)$ in non-smoker cells of BSM workers observed in the present study suggests that low doses of radiation are capable of inducing chromosome and chromatid types of aberrations. Many authors report elevated frequencies of chromatid breaks and fragments in radon-exposed miners and mice (Santa Maria et al., 2007; Elmagd et al., 2008). Chromatid breaks and fragments were also observed in cells of workers engaged in nuclear medicine (Maffei et al., 2004; Kopjar and Garaj-Vrhovac, 2005; Ballardin et al., 2007). Elevated levels of acentric fragments were observed in lymphocytes of nuclear workers exposed to low doses of radiation (Balakrishnan and Rao, 1999; Zakeri and Assaei, 2004). Reports suggest that alpha radiation is capable of inducing sister chromatid exchanges and chromatid aberrations (Brenner and Sachs, 1994; Aghamohammadi et al., 1998; Bilban and Jakopin, 2005). Thus, the enhanced levels of acentric fragments and chromatid breaks observed in the BSM workers could be attributed to exposure to low doses of ionizing radiation.

In order to look for any correlation between the working period and the aberrations, regression plots were generated. No correlation was observed for the $\mathrm{dic}+\mathrm{r}$ or for the ace (data not shown). However, chromatid breaks showed a tendency to increase ( $\mathrm{p}$ value 0.034 ) with the number of working years in the BSM industry (Fig.1). There are other reports which support the observations made in the present study. Donbak et al. (2005) reported significantly enhanced sister chromatid exchanges, and chromatid and chromosomal-type aberrations among coal miners with increase in occupational working years. Similarly, Celik et al. (2007) reported elevated frequencies of sister chromatid exchanges and micronuclei in coal-fired power plant workers over a period of time.

Although our sample population was small, the significantly elevated levels of acentric fragments and chromatid breaks in BSM workers as compared with the 


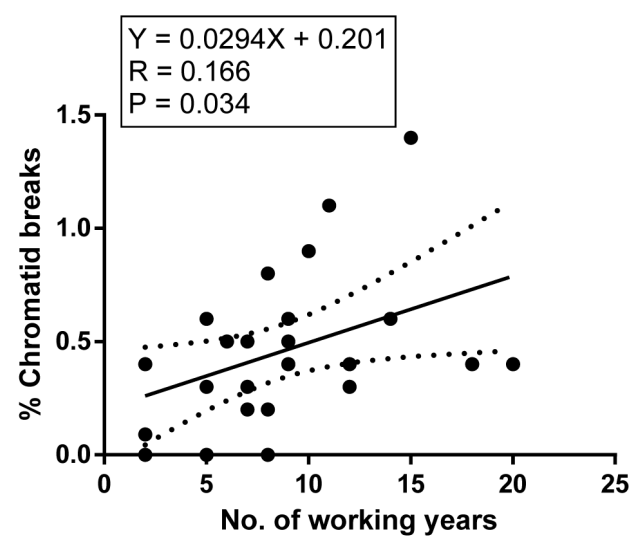

Figure 1 - Regression plot of chromatid breaks as a function of working years in BSM workers (smokers and non-smokers).

controls could be imputed to the occupational exposure to genotoxic compounds (such as heavy metals, silica, etc.) and also to the low doses of ionizing radiation from NORM present in the beach sands.

\section{Conclusion}

The results of this survey confirm the usefulness of the chromosome aberration assay for monitoring employees of the BSM industry. The present study indicates that elevated levels of chromosome and chromatid aberrations among BSM workers indicate exposure to NORM and mine dust. Biodosimetry can thus augment physical dosimetry and help monitor the health effects of both radioactive and other mutagens to which BSM workers may be exposed. Nevertheless, more studies on a larger group are required before recommendations can be made to regulatory authorities to consider those employed in BSM industries as radiation workers.

Acknowledgments. C.Meenakshi, Senior Research Fellow, is thankful to the Department of Atomic Energy (DAE), India for financial assistance. This study forms part of her thesis for a Ph.D. program. The authors thank all the volunteers, and S. Anbumani, Swetha Sonwani, D. Bakkiam and K. Suresh, Radiological Safety Division, for their co-operation and assistance.

\section{REFERENCES}

Aghamohammadi S.Z., Goodhead D.T., Savage J.K. (1998) Induction of sister chromatid exchanges (SCE) in Go lymphocytes by plutonium-238 alpha-particles, Int. J. Radiat. Biol. 53, 909-915. 
Al-sabti K., Lloyd D.C., Edwards A.A., Stegnar P. (1992) A survey of lymphocyte chromosomal damage in Slovenian workers exposed to occupational clastogens, Mutat. Res. 280, 215-23.

Anwar W.A. (1997) Biomarkers of human exposure to pesticides, Environ. Health Perspect. 105, 801-806.

Babu N., Vasumathi N., BhimaRao R. (2009) Recovery of Ilmenite and other Heavy minerals from Teri sands (Red sands) of Tamilnadu, India, J. Miner. Mater. Charact. Eng. 8, 149-159.

Balakrishnan S., Rao S.B. (1999) Cytogenetic analysis of peripheral blood lymphocytes of occupational workers exposed to low levels of ionizing radiation, Mutat. Res. 442, 37-42.

Ballardin M., Antonelli A., Cipollini M., Fallahi P., Scarpato R., Tomei A., Traino C., Barale R. (2007) Induction of chromatid-type aberrations in peripheral lymphocytes of hospital workers exposed to very low doses of radiation, Mutat. Res. 626, 61-68.

Bauchinger M., Schmid E., Einbrodt H.J., Dresp J. (1976) Chromosome aberrations in lymphocytes after occupational exposure to lead and cadmium, Mutat. Res. 40, 57-62.

Bilban M., Jakopin C.B. (2005) Incidence of cytogenetic damage in lead-Zinc mine workers exposed to radon, Mutagenesis 20, 187-191.

Brenner D.J., Sachs R.K. (1994) Chromosomal 'Fingerprints' of prior exposure to densely ionizing radiation, Radiat. Res. 140, 134-142.

Celik M., Donbak L., Unal F., Yuzbasioglu D., Aksoy H., Yilmaz S. (2007) Cytogenetic damage in workers from coal-fired power plant, Mutat. Res. 627, 158-163.

Deknudt G., Léonard A., Ivanov B. (1973) Chromosome aberrations observed in male workers occupationally exposed to lead, Environ. Physiol. Biochem. 3, 132-138.

Dias L.F., Antunes L.M.G., Rezende P.A., Carvalho F.E., Silva C.E., Matheus M.J., Oliveira J.V., Lopes G.P., Pereira A.G., Balarin M.A. (2007) Cytogenetic analysis in lymphocytes from workers occupationally exposed to low levels of ionizing radiation, Environ. Toxicol. Pharmacol. 23, 228-233.

Donbak L., Rencuzogullari E., Yavuz A., Topaktas M. (2005) The genotoxic risk of underground coal miners from Turkey, Mutat. Res. 588, 82-87.

Elmagd M.A., Daif M.M., Eissa H.M. (2008) Cytogenetic effects of radon inhalation, Radiat. Meas. 43, 1265-1269.

Haridasan P.P., Pillai P.M., Khan H., Puranik D. (2006) Natural radionuclides in zircon and related radiological impacts in mineral separation plants, Radiat. Prot. Dosim. 121, 364-369.

IAEA (2001) Cytogenetic Analysis for Radiation Dose Assessment, Technical Report Series No. 405, Vienna.

Johnson F.M. (1998) The genetic effects of environmental lead, Mutat. Res. 410, 123-140.

Kandar M.Z., Bahari I.B. (1995) Radiation-induced chromosomal aberrations among TENORM workers: amang and Ilmenite processing workers of Malaysia, Mutat. Res. 351, 157-161.

Keshava N., Ong T.M. (1999) Occupational exposure to genotoxic agents, Mutat. Res. 437, 175-194.

Kopjar N., Garaj-Vrhovac V. (2005) Assessment of DNA damage in nuclear medicine personnelcomparative study with the alkaline comet assay and the chromosome aberration test, Int. J. Hyg. Environ. Health 208, 179-191.

Lazutka J.R., Lekevièius R., Dedonyte V., Maciulevièiûte-Gervers L., Mierauskiene J., Rudaitiene S., Slapsyte G. (1999) Chromosomal aberrations and sister-chromatid exchanges in Lithuanian populations: Effects of occupational and environmental exposures, Mutat. Res. 445, 225-239.

Leonard A., Deknudt G., Leonard E.D., Decat G. (1984) Chromosome aberrations in employees from fossil-fueled and nuclear-power plants, Mutat. Res. 138, 205-212. 
Lloyd D.C., Lucas J.N., Edwards A.A., Deng W., Valente E., Hone P.A., Moquet J.E. (2001) A study to verify a reported excess of chromosomal aberrations in blood lymphocytes of Nambian uranium miners, Radiat. Res. 155, 809-817.

Maffei F., Angelini S., Forti C.G., Violante S.N., Lodi V., Mattioli S. (2004) Spectrum of chromosomal aberrations in peripheral lymphocytes of hospital workers occupationally exposed to low doses of ionizing radiation, Mutat. Res. 547, 91-99.

Maki-Paakanen J., Sorsa M., Vainio H. (1981) Chromosome aberrations and sister chromatid exchanges in lead-exposed workers, Hereditas 94, 269-275.

Martin F., Earl R., Tawn E.J. (1991) A Cytogenetic study of men occupationally exposed to uranium, Br. J. Ind. Med. 48, 98-102.

Meenakshi C., Mohankumar M.N. (2012) Radon induced chromosome damage in blood lymphocytes of smokers, Res. J. Environ. Toxicology 6, 51-58.

Nordenson I., Nordstrom S., Sweins A., Beckman L. (1982) Chromosomal aberrations in lead- exposed workers, Hereditas 96, 265-268.

Padmala Reddy C.H., Ramana Devi V., Vidyullatha V., Hema Prasad M., Reddy P.P. (2000) Chromosomal aberrations in smokers exposed to metallic dust in mint factory, Rev. Biomed. 11, 87-90.

Prabhavathi A., Fatima K.S., Srinivasa Rao M., Reddy P.P. (2000) Analysis of chromosomal aberration frequencies in the peripheral blood lymphocytes of smokers exposed to uranyl compounds, Mutat. Res. 466, 37- 41.

Pressl S., Edwards A., Stephan G. (1999) The influence of age, sex and smoking habits on the background level of fish-detected translocations, Mutat. Res. 442, 89-95.

Ramalho A.T., Nascimento A.C. (1991) The fate of chromosomal aberrations in 137 Cs- exposed individuals in the Goiania radiation accident, Health Phys. 60, 67-70.

Ramsey J.M, Moore D.H. 2nd., Briner F.J., Lee D.A., Olsen L.A., Senft J.R., Tucker J.D. (1995) The effects of age and lifestyle factors on the accumulation of cytogenetic damage as measured by chromosome painting, Mutat. Res. 338, 95-106.

Rojas E., Herrera L.A., Poirier L.A., Ostrosky-Wegman P. (1999) Are metals dietary carcinogens? Mutat. Res. 443, 157-181.

Santa Maria S.R., Arana M., Ramirez O. (2007) Chromosomal aberrations in peripheral lymphocytes from male native miners working in the peruvian Andes, Genet. Mol. Biol. 30, 1135-1138.

Scheepers P.T. et al.(2002) Biomarkers for occupational diesel exhaust exposure monitoring (biomodem) - A study in underground mining, Toxicol. Lett. 134, 305-317.

Sinues B., Izquierdo M., Perez V. (1990) Chromosome aberrations and urinary thioesters in smokers, Mutat. Res. 240, 289-293.

Smerhovsky Z., Landa K., Rossner P., Juzova D., Brabec M., Zudova Z., Hola N., Zarska H., Nevsimalova E. (2002) Increased risk of cancer in radon-exposed miners with elevated frequency of chromosomal aberrations, Mutat. Res. 514, 165-176.

Suresh K., Ajoy K.C., Dhanasekaran A., Balasundar S., Santhanam R., Gajendiran V., Meenakshisundaram V. (2003) Investigation of Radiation Levels in Beach Sand Mineral Industries - A preliminary Study, Radiat. Prot. Environ. 26, 1-2.

Tanaka K., Kohda A., Toyokawa T., Ichinohe K., Oghiso Y. (2008) Chromosome aberration frequencies and chromosome instability in mice after long-term exposure to low-dose-rate gamma-irradiation, Mutat. Res. 657, 19-25.

Tanaka K., Kamada N. (2009) Distribution of breakpoints on chromatid-type aberration induced by three different radiations, in relation to fragile sites, Indian J. Sci. Technol. 2, 1-9. 
CHROMOSOME ABERRATIONS IN WORKERS OF BEACH SAND MINERAL INDUSTRIES

Topaktas M., Rencüzodullari E., lla H.B., Kayraldiz A. (2002) Chromosome aberration and sister chromatid exchange in workers of the iron and steel factory of iskenderun Turkey, Teratog. Carcinog. Mutagen. 22, 411-423.

Tucker J.D. (2008) Low-dose ionizing radiation and chromosome translocations: A review of the major considerations for human biological dosimetry, Mutat. Res. 659, 211-220.

UNSCEAR (2008) Sources and effects of ionizing radiation united Nations. N.Y.

Voisin P., Benderitter M., Claraz M., Chambrette V., Sorokine-Durm I., Delbos M., Durand V., Leroy A., Paillole N. (2001) The cytogenetic dosimetry of recent accidental over exposure, Cell Mol. Biol. 47, 557-564.

Wolf G., Arndt D., Kotschy-Lang N., Obe G. (2004) Chromosomal aberrations in uranium and coal miners, Int. J. Radiat. Biol. 80, 147-153.

Zakeri F., Assaei R.G. (2004) Cytogenetic monitoring of personnel working in angiocardiography laboratories in Iran hospitals, Mutat. Res. 562, 1-9. 